\title{
The effect of duration of preservation on the quality, MDA level, and DNA damage of post-thawed Bali cattle bull sperm
}

\author{
H. Dwinofanto ${ }^{1}$, Rimayanti ${ }^{2}$, I. Mustofa ${ }^{2 *}$, S. Susilowati ${ }^{2}$, T. Hernawati ${ }^{2}$ \\ ${ }^{1}$ Postgraduate Student of Reproduction Biology, ${ }^{2}$ Department of Veterinary Reproduction, Faculty of Veterinary Medicine, \\ Airlangga University. Campus C Unair, Jl. Mulyorejo, Surabaya-60115, Indonesia, Tel. +62-031-5992377, Fax. +62-031- \\ 5993015, "Corresponding author: imam.mustofa@fkh.unair.ac.id
}

(Received January 11, 2018; Accepted April 19, 2018)

\begin{abstract}
Frozen semen quality is one of many factors that promote successfully of artificial insemination. Preservation at $5^{\circ} \mathrm{C}$ is one of the steps of semen freezing to obtain high fertility sperm after added with the extender. This study was aimed to determined the sperm quality (motility, viability, and membrane integrity), MDA level and DNA damage of post-thawed sperm after being preserved at $5^{\circ} \mathrm{C}$ for different duration. Bali cattle bull semen collected by artificial vagina. Macroscopic and microscopic evaluation of ejaculate was conducted first. Qualified semen was diluted in Tris Aminomethan-Egg yolk and then devided into two treatment group: preserved at $5^{\circ} \mathrm{C}$ for 4 hours (first group) and 22 hours (second group), and continued to processed into frozen semen, and stored overnight. Pre-freezing and post-thawed of semen analysis was conducted based on SNI: 48691:2017 of The National Standardization Agency of Indonesia. Measurement of levels of Malondialdehyde (MDA) was conducted by spectrophotometry at $532 \mathrm{~nm}$ wavelength, meanwhile measurement of sperms DNA damage percentage was performed by Toluidine blue staining. The result of showed that quality of post-thawed sperm (motility, viability, and membrane integrity) was higher $(\mathrm{P}<0.05)$, and MDA level and DNA damage were lower $(\mathrm{P}<0.05)$ in preservation at $5^{\circ} \mathrm{C}$ for 22 hours compared to those of 4 hours. It could be concluded that preservation at $5^{\circ} \mathrm{C}$ longer (22 hours) means sperm had longer chance to adapt with the extender, this implies the higher quality and lower lipid peroxidation.
\end{abstract}

Keywords: Bali bull, preservation, MDA, DNA, post-thawed Available online at http://www.vetmedmosul.com

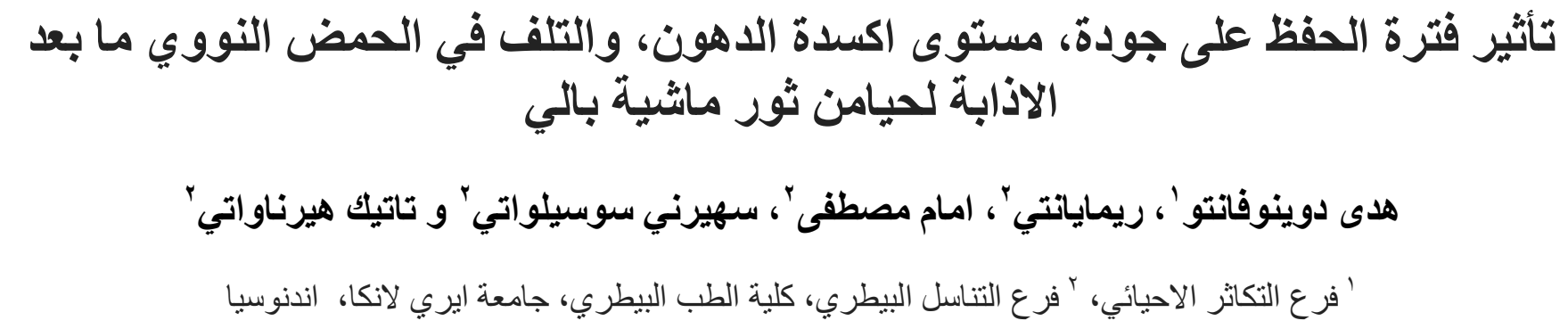

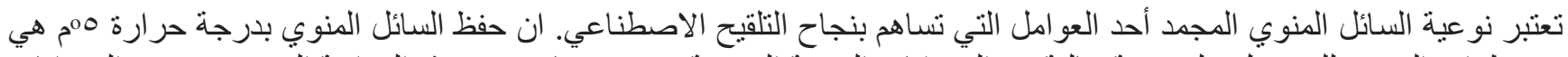

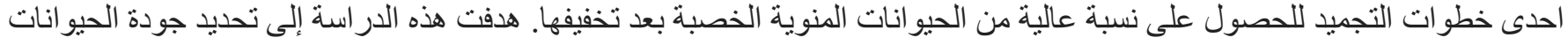

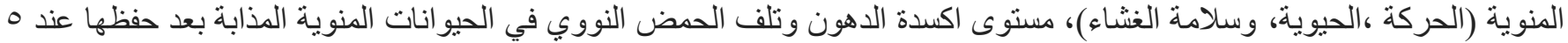

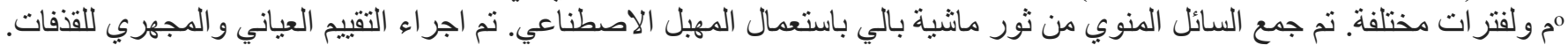

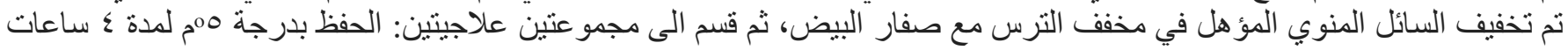

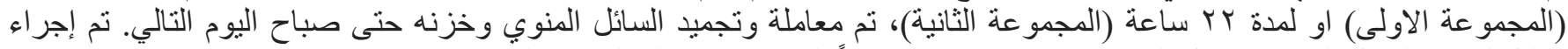

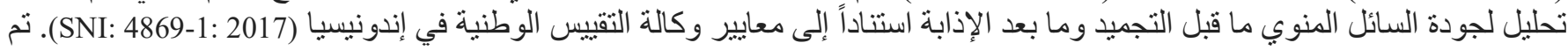

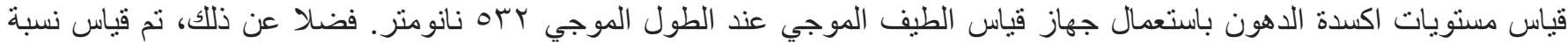




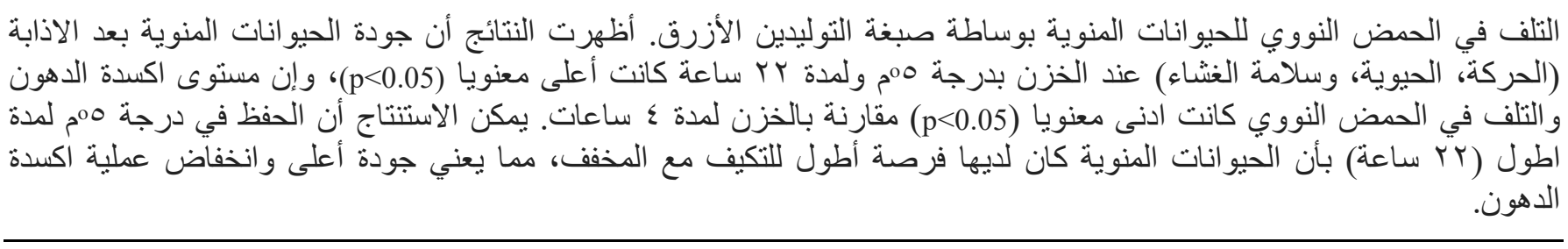

\section{Introduction}

The cryogenic technology of semen is influenced by many factors that can cause changes in sperm cellular and molecular properties. Semen preservation using cryogenic technology has a disadvantageous impact on the sperm. Damage during freezing is common in both the plasma membrane and the sperm nucleus. Damage to the sperm nucleus can cause gene mutations. The freezing process of semen inflict damage to sperm due to changes in its osmotic pressure and the formation of ice crystals $(1,2)$.

The cold shock phenomenon that occurs due to the cooling, freezing and thawing process can cause physical and chemical stress on the sperm membrane. Thus, decrease its viability and fertility (3). The sperm cell damage due to lipid peroxidation is characterized by the decrease in motility and fertilization capacity, damage to intracellular enzymes and plasma membrane structures (4). Lipid oxidation of sperm membranes results in malondialdehyde (MDA) compound which is toxic to the cells. It means MDA may play a major role in the etiology of male infertility (5). An important side effect of freezing was the production of free radicals known as reactive oxygen species (ROS) $(6,7)$. Free radicals alter the function and structure of the sperm plasma membrane integrity (IPM). Excess production of ROS in sperm will cause a number of things such as damage to the fatty acid as the part of sperm membrane, inactivation of the glycolytic enzyme, and break DNA chains that could lead to decreased in the motility and apoptotic occurrence in sperm (8). Currently, there are two methods known for the production of frozen semen which is a one-day method and two-day method. In the one-day method, diluents were added to the semen and preserved at $5^{\circ} \mathrm{C}$ for 4 hours, whereas in the two-day method the diluents were added to the semen and preserved at $5^{\circ} \mathrm{C}$ for $18-22$ hours. Inseminators believed that the quality of frozen semen produced from the one-day method is better than the twoday method. Therefore, it was examined the effects of different preservation duration on the quality, MDA levels and DNA damage of post-thawed Bali cattle bull sperm.

\section{Materials and methods}

This research was conducted in December 2016 to March 2017. Semen obtained from a head of five years old
Bali cattle bull at Singosari National Artificial Insemination Center, Malang, East Java, Indonesia. The semen was collected in the morning, twice a week by using an artificial vagina. Ejaculates were processed to be frozen semen according The Indonesian National Standard number SNI: 4869-1:2017 (production and analysis of frozen semen) of The National Standardization Agency of Indonesia. Semen was diluted in Tris Aminomethan-Egg yolk, examined the quality and then divided into two random groups based on the preservation duration in eight replications. First group was for the preservation duration of 4 hours and second group was for the preservation duration of 22 hours. After passing the preservation time, diluted semen processed in stages of filling in $0.25 \mathrm{ml}$ straw, sealing, labelling, pre freezing at minus $140^{\circ} \mathrm{C}$ for 9 minute, freezed at minus $196^{\circ} \mathrm{C}$ in liquid nitrogen, and finally stored overnight.

Measurement of sperm quality (motility, viability and plasma membranes integrity), MDA levels and DNA damage conducted before freezing, and post-thawed. After thawed at $37^{\circ} \mathrm{C}$ for 30 seconds, each of straw was examined for sperm quality (motility, viability and intact plasma membrane), MDA levels and DNA damage. Semen analysis was done according SNI: 4869-1:2017 of The National Standardization Agency of Indonesia. Measurement of levels of Malondialdehyde (MDA) was conducted by using spectrophotometry at $532 \mathrm{~nm}$ wavelength, meanwhile measurement of sperms DNA damage percentage was performed by using Toluidine blue staining. Data analyzed statistically by using independent $t-$ test at $95 \%$ level of confidence.

\section{Result}

The fresh semen used in this study was evaluated first. This evaluation aims to determine whether the semen is qualified to be processed into frozen semen. Evaluations include color, volume, $\mathrm{pH}$, consistency, concentration, mass movement, individual movement, viability and plasma membranes integrity (Table 1).

Motility of post-thawed sperm after preserved at $5^{\circ} \mathrm{C}$ for 4 and 22 hours were ranged $35-45 \%$ and $45-55 \%$ respectively. There was a significant difference between motility of post-thawed sperm preserved at $5^{\circ} \mathrm{C}$ for 4 hours and for 22 hours $(\mathrm{P}<0.05)$. This indicates the effect of preservation duration to the post-thawed sperm motility. The viability of post-thawed sperm after preserved at $5^{\circ} \mathrm{C}$ 
for 4 hours ranged from 64.3 to $78.2 \%$ while for 22 hours ranged from 77.3 to $86.5 \%$. Based on the statistical analysis, there was a significant difference between viability of post-thawed sperm preserved at $5^{\circ} \mathrm{C}$ for 4 hours and for 22 hours $(\mathrm{P}<0.05)$. This indicates the effect of preservation duration on the post-thawed sperm viability. Intact Plasma Membrane of post-thawed sperm after preserved at $5^{\circ} \mathrm{C}$ for 4 hours ranged from $48.1-62.2 \%$ and for 22 hours ranged from 61.9 to $65.6 \%$. There was a significant difference between plasma membranes integrity of post-thawed sperm preserved at $5^{\circ} \mathrm{C}$ for 4 hours and for 22 hours $(\mathrm{P}<0.05)$. This indicates the effect of preservation duration to the plasma membranes integrity of post-thawed sperm (Table 2).

MDA levels of post-thawed sperm after preserved at $5^{\circ} \mathrm{C}$ for 4 hours ranged from 6.45 to $7.18 \%$ (average $6.8 \pm$ $0.3 \%$ ), while for 22 hours ranged from 6.0 to $7.0 \%$ (average $6.4 \pm 0.4 \%$ ). Based on the statistical analysis, there was a significant difference between post-thawed sperm MDA levels after preserved at $5^{\circ} \mathrm{C}$ for 4 hours and 22 hours $(\mathrm{P}<0.05)$. There was an influence of preservation duration at $5^{\circ} \mathrm{C}$ to post-thawed sperm MDA level (Table 3 ).

Table 1: Quality of Bali cattle bull fresh semen

\begin{tabular}{lc}
\hline Evaluation & Average \\
\hline Volume $(\mathrm{ml})$ & $6.2 \pm 0.8$ \\
Color & Milky white \\
$\mathrm{pH}$ & $6.5 \pm 0.1$ \\
Consistency & Medium \\
Concentration $\left(10^{6} / \mathrm{ml}\right)$ & $1,387.8 \pm 286.6$ \\
Mass Movement & $2+$ \\
Individual Movement $(\%)$ & $73.1 \pm 2.6$ \\
Viability $(\%)$ & $87.8 \pm 2.4$ \\
Intact of Plasma Membrane $(\%)$ & $85.2 \pm 1.8$ \\
MDA Level $(\mu \mathrm{M})$ & $5.4 \pm 0.2$ \\
DNA Damage $(\%)$ & $9.5 \pm 4.4$ \\
\hline
\end{tabular}

Table 2: Post-thawed sperm quality after preserved at $5^{\circ} \mathrm{C}$ with different duration

\begin{tabular}{lccc}
\hline $\begin{array}{l}\text { Duration of } \\
\text { preservation } \\
\text { at } 5^{0} \mathrm{C}\end{array}$ & $\begin{array}{c}\text { Motility } \\
(\%)\end{array}$ & $\begin{array}{c}\text { Viability } \\
(\%)\end{array}$ & IPM (\%) \\
\hline 4 hours & $41.3 \pm 3.5^{\mathrm{a}}$ & $74.1 \pm 5.2^{\mathrm{b}}$ & $56.7 \pm 4.3^{\mathrm{b}}$ \\
22 hours & $50.0 \pm 4.6^{\mathrm{b}}$ & $83.1 \pm 2.8^{\mathrm{b}}$ & $63.5 \pm 1.1^{\mathrm{b}}$ \\
\hline
\end{tabular}

Different superscripts at the same column was significantly differences $(\mathrm{P}<0.05)$.

\section{Discussion}

The results showed that fresh semen used in this research has good quality and qualified to be frozen (Table
1). Based on the standard SNI: 4869-1:2017, the minimum motility, concentration, and viability of pre freezing sperms were $70 \%, 1000 \times 10^{6} / \mathrm{ml}$, and $80 \%$ respectively, and maximum abnormality was $20 \%$. The MDA levels and DNA damage of the fresh semen were very low. This was due to the semen come from selected superior cows and taken care of using a good standard. Sperm of bull that has been selected and raised with good feed and environmental conditions would have high quality of sperm and integrity of DNA (9).

Table 3: Level of of MDA ( $\mu \mathrm{M})$ and percentage of DNA damage of post-thawed sperm with different duration

\begin{tabular}{lcc}
\hline $\begin{array}{l}\text { Duration of preservation } \\
\text { at } 5^{0} \mathrm{C}\end{array}$ & MDA & $\begin{array}{c}\text { DNA } \\
\text { Damage }\end{array}$ \\
\hline 4 hours & $6.8 \pm 0.3^{\text {a) }}$ & $25.4 \pm 5.3^{\text {a) }}$ \\
22 hours & $6.4 \pm 0.4^{\text {b) }}$ & $11.5 \pm 4.8^{\text {b) }}$ \\
\hline
\end{tabular}

Different superscripts at the same column was significantly differences $(\mathrm{P}<0.05)$.

\section{Microscopic quality of post-thawed sperm}

The study found that the preservation duration at $5{ }^{\circ} \mathrm{C}$ showed significantly different results on the post-thawed sperm quality (motility, viability and plasma membranes integrity). Semen quality preserved for 22 hours showed better than those preserved for 4 hours. The longer preservation duration (22 compared to 4 hours) produces better post-thawed sperm quality.

The sperm seem to be more adaptable to the diluents when preserved at $5^{\circ} \mathrm{C}$ for 22 hours. Preservation at $5^{\circ} \mathrm{C}$ intended to give the semen time to adapt to the diluents prior to freezing. Preservation at $5^{\circ} \mathrm{C}$ for 22 hours gives a longer opportunity for the semen to adapt to the diluents. As a result, the sperm are protected from external influences including the occurrence of lipid peroxidation due to ROS. Therefore, maintaining the integrity of the plasma membrane (10). ROS play an important role in sperm physiological processes such as capacitation, acrosome reaction, and signaling processes to ensure fertilization (11). ROS generation and its associated effects are likely to be an important contributor to the reduced sperm motility and functional integrity during liquid preservation of buffalo semen at $4{ }^{\circ} \mathrm{C}$, but ROS generation and its damage had only minor effects during freezing and thawing process (12).

\section{MDA level and DNA damage of post-thawed sperm}

The measurement of malondialdehyde (MDA) level is one of the semen quality assessment by using biochemical methods (13). The possible protective effects of superoxide dismutase (SOD) on sperm parameters are that it prevents MDA production and preserves the antioxidants and intracellular enzymes during preservation (14). MDA levels 
and DNA damage to semen preserved for 22 hours showed lower than semen preserved for 4 hours. It mean the preservation in $5^{\circ} \mathrm{C}$ for 22 hours give longer chance for the semen to adapt with the extender, this implies spermatozoa to be protected from outside impact including lipid peroxidation by ROS and DNA damage could be minimized. In this study, there was a negative correlation between the integrity of cell membranes with MDA levels. The higher levels of MDA in sperm suspension would lead to faster cell membrane damage (15). The higher levels of MDA in sperm and the lower percentage of membrane integrity were decrease the quality of sperm (16). The higher the MDA level and the lower sperm motility will be accelerate the occurrence of cell membrane damage. Thus, the metabolic process will be disrupted, and ATP synthesis would become abnormal. The decreasing of motility and its likeliness to survive would be fatal for sperm (17).

Preservation at $5^{\circ} \mathrm{C}$ for 22 hours showed a lower DNA damage than 4 hours. This is probably due to lower lipid peroxidation levels in the membranes of sperm preserved at $5^{\circ} \mathrm{C}$ for 22 hours. This was proven by the lower levels of MDA. Howefer the MDA levels become the most widely used measure to indicate lipid peroxidation (18). Reactive Oxygen species (ROS) is one of the oxidation agents which in high concentration can be toxic to sperm (19). In addition, the cell membrane damaged, it can result in the destruction of organelles present in cells such as mitochondria and lysosomes (20). Mitochondrial function is where cell respires to produces energy. Furthermore, mitochondrial damage will interfere with metabolic processes and directly affect the movement of sperm. Meanwhile, lysosomal damage results in lysis of enzymes present in sperm. Therefore, damage to the integrity of the sperm membrane also affects the sperm DNA integrity. Finally an increased susceptibility to ROS compromises sperm DNA integrity and consequently reduces embryo quality (21).

\section{Conclusion}

Post-thawed sperm quality (motility, viability and plasma membranes integrity) of Bali cattle bull semen preserved for 22 hours was higher than 4 hours, whereas the MDA levels and DNA damage of 22 hours were lower than those of 4 hours preservation in $5^{\circ} \mathrm{C}$. It was suggested to examined those sperm quality by using in vitro fertilization technique.

\section{References}

1. Susilowati S, Hernawati T. Effect of Insulin-Like Growth Factor-I Complex Protein in Frozen Semen's Diluents to the Quality of Equilibrium Time of Goat Sperm. J Kedokteran Hewan. 2011;5(2):6772 .
2. Susilowati S, Hardijanto, Triana IN. Seminal bull coarse protein reduces occurrence of goat sperm necrosis stored at cold temperature. J Vet. 2011;17 (1)57-63..

3. Chatterjee S, Smith ER, Hanada K, Stevens VL, Mayor S. GPI anchoring leads to sphingolipid-dependent retention of endocytosed proteins in the recycling endosomal compartment. EMBO J. 2001;20:1583-1592.

4. Guthrie HD, Liu J, Critser JK. Osmotic tolerance limits and effects of cryoprotectants on motility of bovine sperm. Biol Reprod. 2002;67:1811-1816.

5. Sanocka D, Kurpisz M. Reactive oxygen species and sperm cells. Reprod Biol Endoc. 2004;2(12):112-117.

6. Gadea J, Selles E, Ruiz S, Coy P, Romar R, Matas C, Campos I. Effect of the presence of glutathione in the thawing diluent on the penetrability capacity of porcine oocytes in vitro. In: Proceedings 14 ICAR: Stockholm, 2-6 Jul 2000. Abstract. 2(17):11

7. Susilowati S, Hardijanto, Triana IN. Bull seminal plasma crude protein decreasing the percentage of necrosisin goat sperm that kept in cold temparature. J Vet. 2016;17(1) :57-63.

8. Halliwell B, Whiteman. Measuring reactive species and oxidative damage in vivo and in cell culture: how should you do it and what do the results mean? Br J Pharmacol. 2004;142(2): 231-255.

9. Priyanto L, Arifiantini RI, Yusuf TL. Detection Of Sperm DNA Damage Infresh and Frozen Semen Using Toluidine Blue Staining. J Veteriner. 2015;16(1):48-55.

10. Amaliya A, Utama S, Hardijanto. Quality, Expression of HSP 70 and DNA Damage on Post-thawed Limousin Bull after Preservation at $5^{\circ} \mathrm{C}$. Veterina Medika. 2017;10(1):77- 86 .

11. Bansal AK and Bilaspuri GS. Impacts of Oxidative Stress and Antioxidants on Semen Functions. Vet Med intl. 2011:1-7.

12. Kadirvel G, Kumar S, Kumaresan A. Lipid peroxidation, mitochondrial membrane potential and DNA integrity of sperm in relation to intracellular reactive oxygen species in liquid and frozenthawed buffalo semen. Anim Reprod Sci. 2009;114:125-134.

13. Kordan W, Fraser L, Wysocki P, Strzezek R, Lecewicz M, Mogielnicka-Brzozowska M, Dziekonska A, Soliwoda D, Koziorowska-Gilun M. Semen quality assessments and their significance in reproductive technology. Pol J Vet Sc. 2013;16:823833.

14. Perumal P. Effect of Superoxide Dismutase on Semen Parameters and Antioxidant Enzyme Activities of Liquid Stored $\left(5^{\circ} \mathrm{C}\right)$ Mithun (Bos frontalis) Semen. J Anim Sci. 2014;54:1-9.

15. Susilowati S. Effect of Insulin-Like Growth Factor-I Complex to the Percentage of Plasma Membranes and Levels of Malondialdehyde Sperm. J Veteriner. 2008;9(4):168-175.

16. Hayati A, Mangkoewidjojo S, Hinting A, Moeljopawiro S. The association of sperm MDA levels with rat sperm membrane integrity (Rattus nervegicus) after 2-Mothoxyethanol exposure. Hayati J Biosci. 11:2006;151-154.

17. Sukmawati E, Arifiantini RI, Purwantara B. Semen Resistance to Freezing Processes in Various Superior Male Cows. JITV. 2014;19(3):168-175.

18. Halliwell B, and Gutteridge J.M.C. Free Radicals in Biology and Medicine. 5th Ed. Oxford University Press. 2015.

19. Saleh RA, Agarwal A, Sharma RK, Nelson DR, Thomas AJJR. Effect of cigarette smoking on levels of seminal oxidative stress in infertile men: a prospective study. Fer Ster. 2002;78:491-499.

20. Candrawati N, Susilowati S, Purnomo B. Measurement of centrifuged post-thawed simental bull sperm core DNA damage using diluter egg yolk skim diluter and soy bean lecithin. Ovozoa. 2014;3(2):225-230.

21. Simoes R, Feitosa WB, Adriano Siqueira AFP, Paula-Lopes FF, Marques MG, Peres MA, Barnabe VH, Visintin JA Nichi M, Ortiz ME. AssumpcaInfluence of bovine sperm DNA fragmentation and oxidative stress on early embryo in vitro development outcome. Reprod. 2013;146:433-441. 